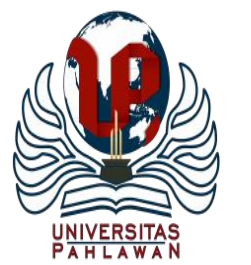

Edukatif : Jurnal Ilmu Pendidikan Volume 3 Nomor 5 Tahun 2021 Halm 2741 - 2748

EDUKATIF: JURNAL ILMU PENDIDIKAN

Research \& Learning in Education

https://edukatif.org/index.php/edukatif/index

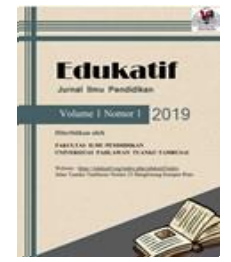

\title{
The Project-Based Learning Approach to Learning Correlational Research for EFL Pre Service Teachers
}

\author{
Kusrin $^{1}$, Elih Sutisna Yanto ${ }^{2}$, Dyah Anungrat Herzamzam ${ }^{3 凶}$ \\ Universitas Singaperbangsa Karawang, Indonesia ${ }^{1,2}$ \\ STKIP Kusuma Negara, Indonesia ${ }^{3}$

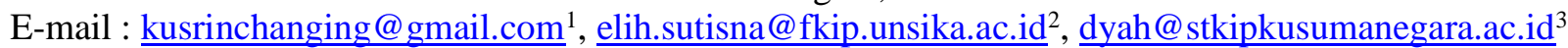

\begin{abstract}
Abstrak
Penelitian ini menggali perspektif mahasiswa perguruan tinggi Indonesia terhadap penelitian korelasi pembelajaran melalui pendekatan Project Based Learning (PBL). Melibatkan 30 mahasiswa semester lima Jurusan Pendidikan Bahasa Inggris yang mengikuti mata kuliah penelitian korelasi selama satu semester, Hal ini dilaksanakan sebelum mahasiswa menulis proposal penelitian. Metode penelitian menggunakan studi kasus. Berdasarkan data yang dikumpulkan dari angket siswa setelah mereka terlibat dalam proyek selama menyelesaikan tugas penelitian korelasi. Hasil penelitian menunjukkan bahwa PBL adalah pendekatan yang baik dan efektif untuk memberdayakan siswa menyelesaikan proyek untuk memberi energi kepada mereka, membangun kerja tim yang kohesif, menyusun prosedur kerja, berdiskusi dan bertukar pendapat, dan menyusun data yang dikumpulkan menjadi proyek yang siap pakai melaporkan penelitian korelasional untuk presentasi di depan audiens sesudahnya. Semoga hasil penelitian ini dapat menginspirasi guru untuk mengembangkan PBL sebagai pendekatan alternatif dalam pembelajaran dengan mata pelajaran yang berbeda untuk membawa siswanya menjadi pembelajar yang mandiri.
\end{abstract}

Kata Kunci: penelitian korelasi; pembelajaran berbasis proyek; calon guru

\begin{abstract}
This research explored Indonesian higher education students' perspective on learning correlation research through Project-based Learning (PBL) approach. It involved 30 fifth-semester pre-service teachers of English Department who were mandated to take part in a correlation research course during the semester before they had to write a research proposal. The results of the research were carried out through a case study design based on the data collected from students' open-response questionnaires after they engaged in projects during the course of completing the correlation research tasks. The results summarized that PBL is a good and effective approach to empower students to complete the project to energize them, to build cohesive teamwork, to devise the working procedures, to discuss and exchange opinions, and scaffold the collected data into a ready project report on the correlational research for a presentation in front of the audiences afterward. Hopefully, the results of the study may inspire teachers to develop PBL as an alternative approach in their instruction with different subjects to bring their students up to independent learners.
\end{abstract}

Keywords: correlation research; project-based learning; pre-service teachers

Copyright (c) 2021 Kusrin, Elih Sutisna Yanto, Dyah Anungrat Herzamzam

$\triangle$ Corresponding author:

Email : dyah@stkipkusumanegara.ac.id

DOI : https://doi.org/10.31004/edukatif.v3i5.824

ISSN 2656-8063 (Media Cetak)

ISSN 2656-8071 (Media Online)

Edukatif : Jurnal Ilmu Pendidikan Vol 3 No 5 Tahun 2021 p-ISSN 2656-8063 e-ISSN 2656-8071 
2742 The Project-Based Learning Approach to Learning Correlational Research for EFL Pre Service Teachers - Kusrin, Elih Sutisna Yanto, Dyah Anungrat Herzamzam

DOI: https://doi.org/10.31004/edukatif.v3i5.824

\section{INTRODUCTION}

A classroom is a kind of miniature society that makes students learn many things and share their emotions among others, ((Muhamad Hugerat, 2016)(Anik Handayani \& Koeswanti, 2021; Yudha, 2019)). It may provide a meaningful circumstance for students to achieve high motivation, discipline, obedience to the regulations. Otherwise, boredom may attack and assassinate students' creativity and interest, ((Muhamad Hugerat, 2016)). because of teacher's preference for a traditional-structured approach and students' less effort to investigate a learning environment, ((Muhamad Hugerat, 2016)). A frustrating experience does not meet Dewey's ideas that teaching should bear students' intention to explore real-world issues (Damopolii, Yohanita, M., \& Febilia H. Malatta, 2018; Darllis, F, \& Miaz, 2020; Sari, Budijanto, \& Amiruddin, 2017) and keep in touch with each other in social interaction, (Goldstein, 2016) as the roots of Project-based Learning.

Project-based Learning is a learning model that arranged knowledge spread out around projects into a structured entity. It was an effective student-centered learning approach (Dole, Bloom, \& Doss, 2017); (Petersen \& Nassaji, 2016) that can empower students positively, ((Dole et al., 2017; Novri Yaldi \& Ermawita, 2021; Rasimin, Yusra, \& Wahyuni, 2021; Topano \& Walid, 2021)). The aim of PBL is to enable students to work in a team, to grow interdisciplinary skills, to promote critical thinking and interpersonal intelligence, and to develop the ability to manage projects, (Gibbes \& Carson, 2014; Kern, 2015; Sari et al., 2017; Shih \& Tsai, 2017; Yudha, Zulela, \& Handayani, 2021)). In this way, Project-based Learning bridged students to participate in active learning to get to the bottom of the real-world problems in order to construct new knowledge by themselves ((Alves et al., 2016; Hunter-Doniger, 2018)) and eventually became autonomous and creative learners, ((Alves et al., 2016; Petersen \& Nassaji, 2016) During the instructional process, students are encouraged to emerge and express their collaborative skills (Dole et al., 2017; Kern, 2015; Petersen \& Nassaji, 2016)) and critical thinking to solve problems (Dole et al., 2017). They keep their leisure time away to complete the projects outside the classroom respectively then to collect information, discuss the information, analyze and solve the problems, make a written or oral report, and end with display, (Petersen \& Nassaji, 2016; Yudha et al., 2021)) or presentation activity to the audience, (Goldstein, 2016) so it remarkably took several weeks or long term to finalize the tasks, (Petersen \& Nassaji, 2016) It was interesting because this learning model emphasized in the students' collaboration and the process of reaching the objectives rather than the achievement itself(Dole et al., 2017; Petersen \& Nassaji, 2016; Rustina, 2015)

Some studies involving pre-service teacher training to explore the impact of the Project-based Learning approach have been done, (Dole et al., 2017; Gibbes \& Carson, 2014; Goldstein, 2016)(Acuña et al., 2011) grasp further about the implementation of the approach, this research focused on students' perspective in learning Correlational Research through PBL.

\section{RESEARCH METHOD}

This case study is one that investigated EFL students' engagement in joining research methodology classes through the PBL approach. This approach has been implemented during the odd semester of 2017/2018 in Higher Education in Indonesia. The main purpose of the study is to explore students' perceptions about the PBL approach in dealing with a project of correlational research.

Throughout the time of the first half of the fifth semester, 30 participants between 20 to 22 years old participated in this study. They had to take the language correlational research as one of the compulsory competencies. They were divided into 6 groups with 5 members of each with one shared randomly topic as the project. Successively, they collected information, discussed the information, analyzed and solved the problems, made a written report, and did the presentation.

Observations, open-response questionnaires, and semi-structured interviews were occupied to collect the data. During the class, the lecturer as a non-participant observer took notes of events occurring to the 
2743 The Project-Based Learning Approach to Learning Correlational Research for EFL Pre Service Teachers - Kusrin, Elih Sutisna Yanto, Dyah Anungrat Herzamzam

DOI: https://doi.org/10.31004/edukatif.v3i5.824

students' activities, especially the ways they communicated and gave responses among others. Open-response questionnaires were shared with the pseudonymous presenters at the end of the course. The questionnaires contained students' perceptions on their preparation before doing the projects, collaboration to complete the projects, presentation of the products to the audiences, and responses to the audiences' questions. Triangulating the results, randomly, 2 students were taken for semi-structured interviews recorded by the chief of the class, and 2 other students were chosen as observers.

Qualitative inductive content analysis was chosen. It consists of: (1) reading all data deeply to identify the meaningful ones and reduce the remains, (2) coding the data based on the similarity, (3) categorizing and the data and theming, (4) making interpretation.

Firstly, the students were given the headline concepts of correlation research for the first week ended for two hours, and a two-hour following week, they were presented about how to do a project through PBL and the way to navigate to complete the project. In the third and the fourth meetings, students did the project both inside and outside the classroom. The fifth through the seventh meetings, students in groups presented the result of the project. Here are the topics of the project randomly shared with the six groups and the schedule of the program:

Table 1

The Schedule of the Program

\begin{tabular}{|c|c|c|c|}
\hline $\begin{array}{c}\text { Time } \\
\text { scheduled }\end{array}$ & Topics & Lasted & Group/s \\
\hline 1st week & $\begin{array}{l}\text { Giving evidence of headline } \\
\text { concept of correlation research }\end{array}$ & 2 hours & All groups \\
\hline 2nd week & $\begin{array}{l}\text { Giving evidence of PBL concept } \\
\text { and the way how to do the project } \\
\text { after the } 30 \text { participants were } \\
\text { divided into } 6 \text { groups }\end{array}$ & 2 hours & All groups \\
\hline \multirow{6}{*}{$\begin{array}{l}\text { 3rd and } 4 \text { th } \\
\text { weeks of } \\
\text { meetings } \\
\text { inside and } \\
\text { outside the } \\
\text { classroom }\end{array}$} & $\begin{array}{l}\text { Paraphrasing the definition and the } \\
\text { purpose of correlational research } \\
\text { adapted from different literatures }\end{array}$ & $\begin{array}{l}2 \text { hours and tentative } \\
\text { time scheduled based on } \\
\text { the agreement of } \\
\text { members of a group }\end{array}$ & The 1st group \\
\hline & $\begin{array}{l}\text { Identifying the research problems, } \\
\text { taking one of the interesting } \\
\text { problem out to become the research } \\
\text { title, and doing theoritical review of } \\
\text { variables and making conclusion }\end{array}$ & $\begin{array}{l}2 \text { hours and tentative } \\
\text { time scheduled based on } \\
\text { the agreement of } \\
\text { members of a group }\end{array}$ & The 2nd group \\
\hline & $\begin{array}{l}\text { Formulating the thinking } \\
\text { framework and hypothesis }\end{array}$ & $\begin{array}{l}2 \text { hours and tentative } \\
\text { time scheduled based on } \\
\text { the agreement of } \\
\text { members of a group }\end{array}$ & $\begin{array}{l}\text { The } 3 \text { rd group collaborates } \\
\text { with the } 2 \text { nd group }\end{array}$ \\
\hline & $\begin{array}{l}\text { Designing the research, } \\
\text { determining the population and } \\
\text { sampling technique }\end{array}$ & $\begin{array}{l}2 \text { hours and tentative } \\
\text { time scheduled based on } \\
\text { the agreement of } \\
\text { members of a group }\end{array}$ & The 4th group \\
\hline & $\begin{array}{l}\text { Formulating the conceptual and } \\
\text { operational definitions of the } \\
\text { variables }\end{array}$ & $\begin{array}{l}2 \text { hours and tentative } \\
\text { time scheduled based on } \\
\text { the agreement of } \\
\text { members of a group }\end{array}$ & $\begin{array}{l}\text { The 5th group colaborates } \\
\text { with the } 2 \text { nd group }\end{array}$ \\
\hline & $\begin{array}{l}\text { Determining the technique of } \\
\text { collecting and analyzing data }\end{array}$ & $\begin{array}{l}2 \text { hours and tentative } \\
\text { time scheduled based on } \\
\text { the agreement of } \\
\text { members of a group }\end{array}$ & $\begin{array}{l}\text { The 6th group collaborates } \\
\text { with the 5th group }\end{array}$ \\
\hline
\end{tabular}


2744 The Project-Based Learning Approach to Learning Correlational Research for EFL Pre Service Teachers - Kusrin, Elih Sutisna Yanto, Dyah Anungrat Herzamzam

DOI: https://doi.org/10.31004/edukatif.v3i5.824

\begin{tabular}{lrlll}
\hline $\begin{array}{l}5 \text { th, } \\
\text { and } \\
\text { weeks }\end{array}$ & 7th & Presentation the project results & 1 hour of each group & $\begin{array}{l}\text { In turn, each group does } \\
\text { presentation and 5 others } \\
\text { do observation and prepare } \\
\text { questions }\end{array}$ \\
\hline
\end{tabular}

\section{RESULT AND DISCUSSION}

Research findings describe three focuses of students' perspectives on learning correlational research. The focuses are students' preparation before doing the projects, collaboration to complete the projects, and presentation of the products to the audiences, and responses to the audiences' questions. Here are the original details:

1. Students' perceptions on preparation before doing the projects of correlational research.

The students were asked what they had done before they decided to start doing the project and what they had felt. Most students responded that they discussed the ways to materialize a paper of correlational research method. They divided materials and each member navigated them in journals, e-books, and printed materials. In this way, they felt that they found themselves becoming independent learners as some presenters' perceptions (pseudo-names) conveyed below:

Gizzallex Janey: "The assignment is really good, why? The students do or find many sources that refer to the assignment and it makes the student become more independent to themselves." (presenter -1)

Lalisa Manoban: "The method that Mr. John (lecture's pseudo-name) chooses is very effective." (presenter -2)

Mawar: "We are free to explore learning materials or resources from books, journals, and others." (presenter -3)

2. Students' perceptions on collaboration to complete the projects

The students were asked what they felt to work together with their friends in a team. In this stage, students in the team made a paper based on the collected materials and summarized the paper into PowerPoint for a presentation. All students expressed that to complete the project, they worked together with their classmates. According to two presenters and one interviewee, PBL is a good method that makes them pleasant because they may discuss and exchange opinions among them. Some of them said:

Mawar: "This activity is quite pleasant because my friends and I had to navigate the learning materials from various sources and discuss them and exchange opinions among of us." (presenter -3)

Barbara Palvin: "The lecturer gives an assignment to each group that makes the teamwork more cohesive." (presenter -2)

Laurynn O'Hara (audiance as an interviwee): "I think it's a good method to empower us to work together to complete a task."

3. Students' perceptions on presenting the products to the audiences and giving responses to their questions

The students were asked what they did before the presentation. All students prepared their parts as seriously as they could. They tried to review their preparations and understand, memorize, read the materials many times. Before the presentation, they practiced in the classroom, in front of the mirror, in the toilet of the campus, or bedroom. Here are some comments presenters delivered:

Anoname: "I always practice my turn in my room using my words and this way helps me paraphrase the materials easier than memorize the originals." (presenter -1)

Chelsea Islan: "I practice to deliver the topic in front of the dormitory and toilet of the campus mirrors as if the audiences were there." (presenter --2) 
2745 The Project-Based Learning Approach to Learning Correlational Research for EFL Pre Service Teachers - Kusrin, Elih Sutisna Yanto, Dyah Anungrat Herzamzam

DOI: https://doi.org/10.31004/edukatif.v3i5.824

Bumblebee: "At first, I rewrite the materials in my note book and then I read and understand them. Finally, I stand up in front of my roommate to practice presentation.” (presenter -3)

The students were also asked what they felt during the presentation. Before engaging in the real presentation, some students feel nervous, uneasy, awkward, and ashamed. Some others feel convenient because they can improve confidence and enhance bravery in speaking ability. Here are two presenters and one interviewee expressed their opinions:

Ini: "When the members of our group gave a presentation and spoke in front of our classmates, we felt nervous and uneasy to deliver the materials." (presenter -1)

Salma Diana: "I do not deny that during the presentation I always feel awkward." (presenter -2)

Barbara Palvin: "Presentation in front of our classmates can enhance our bravery to speak English and improve our fluency." (interviewee -2)

Chelsea Islan: "Delivering the materials in front of audiences, I felt I could encourage myself to improve my confidence." (presenter-2)

The following question is about their thoughts on the presentation event. Although the presentation is a challenge, most students think that it is a good part of PBL because it can stimulate direct practice in front of the audience. This event may lead them to enrich the vocabulary and practice improvisation and paraphrasing. Three presenters and one observer expressed their opinions below:

Juleha: "Doing presentation is quite challenging for us because we have to explain the materials clearly and it will become a big problem if the audiences do not understand the content of it." (presenter -2)

Alexander, M. M: "At first, I should understand my materials and memorize the main points, and I improvise them by way of paraphrasing then." (observer)

Kim Wendy: "Doing presentation in front of the class is a good way of speaking practice." (presenter 3)

Anoname: "Before the presentation, I practice in my room using my own words." (presenter -1)

The students were also asked what they thought of their friends' questions to their presentation. As the continuation of the presentation event, audiences are given a chance to ask questions. The two parties, the presenters and the questioners, engage in a further discussion of the presented materials. It is a gripping moment for the presenters and an interesting one for the questioners. The presenters feel worried, afraid, nervous, and confused because of not being able to answer the questions. To make matters worst, the questions sometimes are not clear or very difficult to answer. On the one hand, the questioners should relieve their difficulties in the hope of giving logical and satisfying answers. Above the contradiction, both parties agree that question and answer event makes student active, enthusiastic, and excited to generate critical thinking and self-confidence express their opinions. The presenters discuss each question addressed before they decide to answer correctly. Here are the perceptions expressed by two presenters, two interviewees, and two observers:

Eleanor Tomlinson: "We in group have chance to discuss the questions given by the audiences and try to find the answers as good as we can." (presenter -1)

Salvina Mewangi (audience as an interviewee): "My friends were so worried. Most of them were afraid of not being able to answer the questions from the audiences."

Melati: "Sometimes between the questions from the audiences and presenters' answers are not connected to each other for the question is not clear or the answer is confusing." (presenter - 3)

Bilkis, K.,R. (audience as an observer): "The student is enthusiastic asking to the presenter or the lecturer." 
2746 The Project-Based Learning Approach to Learning Correlational Research for EFL Pre Service Teachers - Kusrin, Elih Sutisna Yanto, Dyah Anungrat Herzamzam

DOI: https://doi.org/10.31004/edukatif.v3i5.824

Alexander, M. M (audience as an observer): "My friends were so excited. Most of them wanted to ask."

Gizzallex Janey (audiance as an interviewee): "I think, in this case the students can improve their thoughts to become critical thinkers and it provides opportunities for other students to give their opinions"

PBL is a good and effective approach to empower students to complete the project. It energizes them to build cohesive teamwork to devise the working procedures, to discuss and exchange opinions, and to scaffold the collected data into a ready project report for a presentation in front of the audiences afterward. So, this student-centered learning reflects a miniature society that provides students from different backgrounds to interact with each other based on a mutual understanding communication to achieve the formulated objectives. PBL is also able to push students to become independent learners. Each member of a group is free to search his/her task from various sources, such as journals, e-books, and printed materials. He/She analyzes it deeply to convince whether his/her task can scientifically be accounted for before being handed down to the group for a further discussion. Although taking a considerable long time to carry out the project is one unavoidable challenge of PBL, it is precisely a meaningful circumstance of learning that may warrant students' competencies on bivariate correlational research. Based on the findings of the researchers as well as some previous researchers showed that the model Problem-Based Learning can improve students' abilities because the PBL model is one of the learning models that stimulate student participation actively active and creative in dealing with contextual problems that usually occur in everyday life. Research, in this case, there are still some limitations such as the lack of lecturers who can manage the class properly Using the Project-Based Learning model, not all students are active in learning so that extra effort is needed to make students participate in class, the application of the Project-Based Learning model requires a long time in learning because students explore new concepts by themselves using their knowledge.

\section{CONCLUSION}

This study investigates EFL Pre-Service Teachers' perceptions on learning Correlational Research through the PBL approach. The following summary reflects the focus. Presentation as a peak phase of PBL is always thrilling students' hearts. They consider it as an extraordinary event that needs undivided attention to conceive. Reading materials many times before being presented and practicing presentation in the classroom, in front of the mirror, in the toilet of the campus, bedroom, or dormitory are parts of their preparation. They endeavor to keep nervousness, inconvenience, and unconfidence away from them so that they can memorize and paraphrase the materials well. Moreover, having accomplished the presentation, they are engaged in a gripping moment, free question and answer episode from their classmates. The real fact proves that the presenters feel worried, afraid, nervous, and confused about not being able to answer the questions. On one side, they feel excited for many classmates show of hands enthusiastically to ask them and both parties may generate critical thinking and self-confidence. Although this approach is effective to stir up students to work in a team and accustom them to be independent, critical thinking, and self-confidence learners at once, the group products and the ways to present them to the audiences are not always satisfactory that sometimes make them complicated, confused, and frustrated. Therefore, the lecturer's reinforcement should be taken into consideration to complete the process of the PBL.

\section{REFERENCES}

Acuña, M. H., Ogilvie, K. W., Baker, D. N., Curtis, S. A., Fairfield, D. H., \& Mish, W. H. (2011). The Global Geospace Science Program and its investigations. In Space Science Reviews (Vol. 71). https://doi.org/10.1007/BF00751323

Alves, A. C., Sousa, R. M., Fernandes, S., Cardoso, E., Carvalho, M. A., Figueiredo, J., \& Pereira, R. M. S. 
2747 The Project-Based Learning Approach to Learning Correlational Research for EFL Pre Service Teachers - Kusrin, Elih Sutisna Yanto, Dyah Anungrat Herzamzam

DOI: https://doi.org/10.31004/edukatif.v3i5.824

(2016). Teacher's experiences in PBL: implications for practice. European Journal of Engineering Education, 41(2), 123-141. https://doi.org/10.1080/03043797.2015.1023782

Anik Handayani, \& Koeswanti, H. D. (2021). Meta-Analisis Model Pembelajaran Problem Based Learning (PBL) Untuk Meningkatkan Kemampuan Berpikir Kreatif. Jurnal Basicedu, 5(2), 1060-1066.

Damopolii, Yohanita, I., M., A., \& Febilia H. Malatta, F. M. Y. (2018). Pengaruh Model Pembelajaran Berbasis Masalah Terhadap Hasil Belajar Kognitif Siswa Kelas VII SMP. Angewandte Chemie International Edition, 6(11), 951-952., 3(1), 43-52.

Darllis, N., F, F., \& Miaz, Y. (2020). Pengembangan Desain Pembelajaran Model Assure Berbasis Problem Based Learning Menggunakan Komik di Sekolah Dasar. Jurnal Basicedu, 5(1), 334-342. https://doi.org/10.31004/basicedu.v5i1.689

Dole, S., Bloom, L., \& Doss, K. K. (2017). Interdisciplinary Journal of Problem-Based Learning Engaged Learning: Impact of PBL and PjBL with Elementary and Middle Grade Students Problem-based Learning Special iSSue On cOmpetency OrientatiOn in prOblem-baSeD learning. Interdisciplinary Journal of Problem-Based Learning, 11(2), 7-11. Retrieved from https://doi.org/10.7771/15415015.1685

Gibbes, M., \& Carson, L. (2014). Project-based language learning: An activity theory analysis. Innovation in Language Learning and Teaching, 8(2), 171-189. https://doi.org/10.1080/17501229.2013.793689

Goldstein, O. (2016). A project-based learning approach to teaching physics for pre-service elementary school teacher education students. Cogent Education, 3(1), 1-12. https://doi.org/10.1080/2331186X.2016.1200833

Hunter-Doniger, T. (2018). Project-Based Learning: Utilizing Artistic Pedagogies for Educational Leadership. Art Education, 71(2), 46-51. https://doi.org/10.1080/00043125.2018.1414542

Kern, J. (2015). Implementation of new technology - The regulator's perspective. SAE Technical Papers, 7 , 5-9. https://doi.org/10.4271/902340

Muhamad Hugerat. (2016). How teaching science using project-based learning strategies affects the classroom learning environment. Learning Environments Research, 21(10), 51-51. https://doi.org/10.1007/s35152-019-0134-8

Novri Yaldi, \& Ermawita. (2021). Pengembangan Perangkat Pembelajaran Berbasis Pendekatan Problem Based Learning di Sekolah Dasar. Jurnal Basicedu, 5(2), 1060-1066.

Petersen, C., \& Nassaji, H. (2016). Project-based learning through the eyes of teachers and students in adult ESL classrooms. Canadian Modern Language Review, 72(1), 13-19. https://doi.org/10.3138/cmlr.2096

Rasimin, R., Yusra, A., \& Wahyuni, H. (2021). Efektivitas Layanan Bimbingan Kelompok Berbasis Problem Based Learning untuk Meningkatkan Komunikasi Interpersonal Siswa. Edukatif: Jurnal Ilmu Pendidikan, 3(2), 314-320. https://doi.org/10.31004/edukatif.v3i2.261

Rustina, R. (2015). Pengaruh Penggunaan Model Problem Based Learning terhadap Peningkatan Kemampuan Penalaran Mahasiswa pada Mata Kuliah Kalkulus III. Jurnal Penelitian Pendidikan Dan Pengajaran Matematika, 1(1), 49-54.

Sari, N. P., Budijanto, B., \& Amiruddin, A. (2017). Pengaruh penerapan model pembelajaran problem based learning dipadu numbered heads together terhadap keterampilan metakognitif dan kemampuan berpikir kritis geografi siswa Sma. Jurnal Pendidikan: Teori, Penelitian, Dan Pengembangan, 2(3), 440-447. Retrieved from http://journal.um.ac.id/index.php/jptpp/article/view/8720

Shih, W. L., \& Tsai, C. Y. (2017). Students' perception of a flipped classroom approach to facilitating online project-based learning in marketing research courses. Australasian Journal of Educational Technology, 33(5), 32-49. https://doi.org/10.14742/ajet.2884

Topano, A., \& Walid, A. (2021). EDUKATIF : JURNAL ILMU PENDIDIKAN Pengaruh Problem Based 
2748 The Project-Based Learning Approach to Learning Correlational Research for EFL Pre Service Teachers - Kusrin, Elih Sutisna Yanto, Dyah Anungrat Herzamzam

DOI: https://doi.org/10.31004/edukatif.v3i5.824

Learning ( PBL ) Terhadap Kemampuan Pemecahan Masalah dan Hasil Belajar Kognitif Siswa SMA Negeri 10 Kota Bengkulu. 3(3), 717-727.

Yudha, C. B. (2019). Penerapan Project Based Learning dalam Mata Kuliah Penelitian Tindakan Kelas. 4(1), 114-124.

Yudha, C. B., Zulela, \& Handayani, T. (2021). Learning in Networks During the Covid-19 Pandemic. Jurnal Basicedu, 5(2), 1060-1066. 